\title{
Outbreaks of Bagworms and their Natural Enemies in an Oil Palm, Elaeis Guineensis, Plantation at Hutan Melintang, Perak, Malaysia
}

\begin{abstract}
A field study on population of bagworms was carried out in oil palm, Elaeis guineensis, plantation at Hutan Melintang, Perak, Malaysia from October 2005 to April 2006. Sampling was conducted at 14 days interval. The result suggests bagworm infestation was not correlated with amount and distribution of rainfall as being claimed by many planters. The result also shows that Pteroma pendula (Lepidoptera: Psychidae) was the most dominant bagworm species among all of the bagworms recorded. Natural enemies, predators, parasitoids and some entomopathogenic fungi, contributed to mortality of the bagworms. Larvae of Callimerus arcufur (Coleoptera: Cleridae) were the most common predator attacking the bagworms. Cosmelestes picticeps (Hemiptera: Reduviidae) was also observed attacking $\mathrm{P}$. pendula. Among three species of parasitoids, Dolichodenidea metasae (Hymenoptera: Braconidae) was the most significant parasitoid of bagworm and this parasitoid commonly attacked by a hyperparasitoid, Pediobius imbrues (Hymenoptera: Braconidae). Two species of entomopathogenic fungi, Peacilomyces fumosoroseus and Metarhizium ansopliae, were isolated from fungal-infected bagworms. Even though natural enemies were affecting the bagworm populations in the field and their resultant impact in controlling the bagworm populations in the field was still far from desirable.
\end{abstract}

Keyword: Psychidae, bagworms, Pteroma pendula, natural enemies, oil palm, Elaeis guineensis 